\title{
Rainfed Evaluation of Genotypes for Seed Yield and Yield Components in Sunhemp (Crotalaria juncea L.) and Dhaincha (Sesbania aculeata L.)
}

\author{
T. Shobha Rani ${ }^{1 *}$, T. Sukruth Kumar ${ }^{2}$, U. Nagabhushanam ${ }^{3}$ and P. Jaganmohan Rao ${ }^{4}$ \\ ${ }^{1}$ (Plant Breeding), Agricultural Research Station, Nathnaipally, India \\ ${ }^{2}$ (Soil Science), Agriculture Polytechnic College, Jogipet, India \\ ${ }^{3}$ (Agronomy), Regional Agricultural Research Station, Warangal, India \\ ${ }^{4}$ Regional Agricultural Research Station, Warangal, India \\ *Corresponding author
}

K e y w o r d s
Green manures,
Sunhemp,
Dhaincha, Seed
yield, Rainfed
Article Info
$\begin{aligned} & \text { Accepted: } \\ & 10 \text { March } 2020 \\ & \text { Available Online: } \\ & 10 \text { April } 2020\end{aligned}$

\section{A B S T R A C T}

In agriculture, green manure is created by leaving uprooted or sown crop parts to wither on a field so that they serve as a mulch and soil amendment. The plants used for green manure are often cover crops grown primarily for this purpose. In the present study ten Sunhemp (Crotalaria juncea L.) and Eleven Dhaincha (Sesbania aculeata L.) genotypes were studied for seed yield during kharif, 2018 under rainfed ecosystem. Observations recorded on Days to $50 \%$ flowering, Days to maturity, Plant height $(\mathrm{cm})$, Number of branches per plant, Number of pods shattered per plant, Number of dry pods, Number of green pods, Number of seeds/pod , Test weight (g) and Seed yield per plant (g). Significantly higher values recorded compared to the check for all the characters except Plant height in Sunhemp and Test weight in Dhaincha. Seed yield per plant exhibited a wide amount of variation varying from 13.30 to $27.77 \mathrm{~g}$ per plant in Sunhemp. The overall mean was $18.94 \mathrm{~g}$. Highest seed yield recorded in NTPSH 04 (27.77 g) followed by NTPSH 03 (26.12 g). Whereas in Dhaincha, the lowest seed yield recorded in NTPD $04(14.46 \mathrm{~g})$ and highest in NTPD 08 (34.67 g). However the high biomass production in terms of root and shoot is criteria in green manures. Selection will be effective for entry with high biomass and high seed yield.

\section{Introduction}

India has changed from a region of food scarcity to food sufficiency by increased fertilizer use with subsidized prices, but use of organic manures including green manure, declined substantially. Inorganic fertilizers are

\begin{abstract}
becoming more expensive, therefore sustainability of soil productivity has become a question. Hence, alternate sources to supplement inorganic fertilizers are thought. Green manuring are low cost and effective technology in minimising cost of fertilizers and safe guarding productivity. Crops grown
\end{abstract}


for the purpose of restoring or increasing the organic matter content in the soil are called Green manure crops. Use of Green manure crops in cropping system is called 'Green Manuring' where the crop is grown in situ or brought from outside and incorporated when it is purposely grown.

Green manure crop should posses the characteristics such as; multipurpose use, short duration, fast growing, high nutrient accumulation ability, tolerance to shade, flood, drought and adverse temperatures, wide ecological adaptability, efficiency in use of water, early onset of biological nitrogen fixation, high $\mathrm{N}$ accumulation rates, timely release of nutrients, photoperiod insensitivity, high seed production, high seed viability, ease in incorporation, ability to cross-inoculate or responsive to inoculation, pest and disease resistance and high $\mathrm{N}$ sink in underground plant parts. In line with these properties, Sunhemp (Crotalaria juncea L) and Dhaincha (Sesbania aculiata L) are the suitable species for green manuring with high biomass production as 20-25 t/ha (Thipathi et al., 2013).

The lack of availability of adequate quality seeds at appropriate time at reasonable price for small holding and marginal farmers becomes a major constraint in Sunhemp and Dhaincha cultivation. Quality seed production of Sunhemp and Dhaincha is given meagre importance inspite huge demand from farmers. Further, possibility of seed production under rainfed situation paves way for identification of genotypes with high water use efficiency.

\section{Materials and Methods}

The material for the study comprised 10 and 11 genotypes in Sunhemp and Dhaincha respectively including local check. These genotypes were collected from different parts of India representing diverse eco-geographic origin. The experiment was conducted at Agricultural Research Station, Nathnaipally during Kharif, 2018 in a randomized block design with three replications. Each genotype was sown during June II FN, 2018 in six rows of $4 \mathrm{~m}$ length at a distance of $30 \mathrm{~cm}$ between the rows and $10 \mathrm{~cm}$ between the plants within the rows in Sunhemp and $45 \mathrm{~cm}$ between the rows and $20 \mathrm{~cm}$ between the plants within the rows in Dhaincha. Recommended agronomic practices were followed to raise a healthy crop. Observations were recorded on each entry on five randomly selected plants for yield and yield contributing characters viz., days to $50 \%$ flowering, days to maturity, plant height $(\mathrm{cm})$, number of branches per plant, number of pods shattered per plant, number of dry pods, number of green pods, number of seeds/pod, test weight ( $\mathrm{g}$ ) and seed yield per plant $(\mathrm{g})$. Simple analysis was done for Mean, Range, CV and CD.

\section{Results and Discussion}

Basically the trial was conducted during kharif under rainfed ecosystem. This is mainly to evaluate the survival ability of the genotypes under scarce rainfall situation in Medak district, Telangana State. Usually quality seed availability in time is big constraint in Telangana State. As per reality the best season for any crop is during Rabi. But availability of water during summer months will be a question. Further most of the area in state is under rainfed situation. These areas can bring under cultivation of green manures seed production (Chandrasekhar, 2013). Hence the present study was conducted to evaluate possibility of green manures seed production during Kharif.

Agricultural Research Station, Nathnaipally is established during the year 2008 with the financial assistance of Non-Plan, Professor Jayashankar Telangana State Agricultural 
University formerly Acharya N.G. Ranga Agricultural University. ARS, Nathnaipally is situated in Narsapur Mandal, Medak District, Telangana, India. Its geographical coordinates are $17^{\circ} 44^{\prime} 9^{\prime \prime}$ North, 78 $16^{\prime} 54^{\prime \prime}$ East on globe. The environment in area is tropical. Farming system is rainfed and soil type is Red sandy loam (shallow-medium). It is characterized by the annual rainfall of $732.5 \mathrm{~mm}$ and temperatures ranging from $15^{\circ}$ $\mathrm{C}$ to $45^{\circ} \mathrm{C}$.

Sunhemp and Dhaincha Trials were sown on 17.06.2018 and 19.06.2018 respectively. During crop growth period $496.4 \mathrm{~mm}$ of rainfall was received from June to October, 2018 in 35 rainy days. Due to which crop revealed luxuriant growth. Sufficient rainfall was received during June, July and August helped in increase in vegetative growth and delayed flowering in Sunhemp. Where as usual flowering period was observed in Dhaincha. Overall, increased vegetative growth and increased number of branches facilitated more number of flowers, pods and seed yield in both Sunhemp and Dhaincha.

Seed yield is a complex trait, polygenic and highly influenced by environmental conditions. A successful breeding programme depends upon the genetic variability present among the different genotypes. Phenotypic selection of parents for hybrids based only on their performance alone may not always be available procedure since phenotypically superior genotypes may yield inferior hybrids and/or poor recombinants in the segregating generations.

Hence simple analysis on Mean, Range, CV and $\mathrm{CD}$ for days to $50 \%$ flowering, days to maturity, plant height $(\mathrm{cm})$, number of branches per plant, numberof pods shattered per plant, number of dry pods per plant, No of green pods, number of seeds/pod, test weight (g) and seed yield per plant (g) was studied in
Sunhemp and Dhaincha (Table 1 and 2).

\section{Days to $50 \%$ flowering}

Overall mean for days to $50 \%$ flowering was noticed as 72 days in Sunhemp and 48 days in Dhaincha. This reveals rains during vegetative period delayed flowering in Sunhemp and after initiation of flowering there was decline in growth observed. While, Dhaincha not effected with continuous moisture availability and even after flowering growth continued. In Sunhemp NTPSH 06 (68 days) was early to flower where as NTPSH 05 (76 days) was taken highest number of days for flowering.

Similarly, in Dhaincha NTPD 02 (46 days) was early to flower and NTPD 10 flowered in 51 days. For biomass production and green manuring, late flowering would be the desirable trait. Three genotypes viz., NTPSH 05, NTPSH 07 and NTPSH 08 recorded significantly more number of days taken for flowering compared to check (72 days) in Sunhemp. Where as in Dhaincha only one entry NTPD 10 recorded more number of days for flowering over check (49 days).

\section{Days to maturity}

Maturity duration varied from 136 days to 148 days with a mean of 141 days in Sunhemp. NTPSH 06 was early while NTPSH 09 was late in maturity. Whereas mean number of days taken for maturity in Dhaincha was 127 with range 123 days (NTPD 10) to 136 days (NTPD 05). Variation in days to maturity provides ample scope for selection of early and late maturing plants for further improvement. None of the genotype recorded more number of days for days to maturity over check (146 days) in Sunhemp, while in Dhaincha only one genotype NTPD 05 recorded more days over check (128 days). 


\section{Plant height (cm)}

In Sunhemp, Plant height varied from 83.60 to $123.60 \mathrm{~cm}$ with an overall mean of 100.66 $\mathrm{cm}$. Among all the genotypes NTPSH 05 $(83.60 \mathrm{~cm})$ was dwarf, while NTPSH 05 $(123.60 \mathrm{~cm})$ was the tallest.

Similarly in Dhaincha for plant height not much variation is observed. Plant height was increased even after flowering. Secession of rains resulted in decline in terms of plant height increase.

Mean plant height recorded was $261.37 \mathrm{~cm}$ with range $226 \mathrm{~cm}$ (NTPD 07- shortest) to $287.2 \mathrm{~cm}$ (NTPD 09 - tallest). Compared to the check $(89.6 \mathrm{~cm})$, five genotypes viz., NTPSH 01, NTPSH 02, NTPSH 03, NTPSH 06 and NTPSH 08 grown significantly taller in Sunhemp. While it was three genotypes found significantly taller (NTPD 03, NTPD 08 and NTPD 09) over check $(267.3 \mathrm{~cm})$ in Dhaincha.

\section{Number of branches per plant}

Number of branches varied from 3.8 (NTPSH 05) to 7.8 (NTPSH 06) with overall mean of 5.58 branches per plant in Sunhemp. While in Dhaincha less number of branches per plant observed in NTPD 01 (14.8) and highest in NTPD 08 (24.6). Results indicated that for any green manure crop more branches per plant may give more biomass, is desirable trait and there is possibility for improvement through selection of this character and breeder may have reliable benefits in next generation with respect to this character.

In all the genotypes number of branches found significantly superior in Sunhemp compared to the check (4.0) except NTPSH 07 . Where as in Dhaincha, four genotypes namely NTPD 02, NTPD 06, NTPD 08 and NTPD 09 found significantly superior over check (18.2).

\section{Number of shattered pods per plant}

However number of shattered pods observed in Sunhemp genotypes was nil (0) indicates shattering is not a problem in Sunhemp. Where as in Dhaincha shattering is observed with mean value of 7.60. Among all the genotypes in four genotypes no shattering was observed namely; NTPD 01, NTPD 06, NTPD 07 and NTPD 08. While highest shattering was noticed in NTPD 04 (15.2). Results indicates shattering plays negative selection role in Seed yield. Two entries namely NTPD 04 and NTPD 05 were recorded significantly higher shattered pods over check (10.2).

\section{Number of dry pods per plant}

In Sunhemp, number of dry pods is equal to total number of pods which is ranged from 47.4 (NTPSH 07) to 116.2 (NTPSH 03) with mean value of 88.94. In Sunhemp delayed flowering, increased vegetative growth and increased number of branches solely attributed to the increased number of pods. This will have direct selection pressure on yield. Similarly in Dhaincha, number of dry pods varied from 30.6 (NTPD 05) to 101 (NTPD 06) with a mean value of 64.85. In sunhemp, all the genotypes recorded significantly more number of dry pods except NTPSH 06 and NTPSH 07 compared to the check (48.2). While in Dhaincha, NTPD 01, NTPD 02, NTPD 03, NTPD 07, NTPD 08 and NTPD 10 produced significantly more number of pods over check (46.4)(Venkanna, 2014).

\section{Number of green pods per plant}

No green pods observed at maturity in Sunhemp reveals the synchronous maturity was observed. Where as in Dhaincha synchronous maturity is difficult to find i.e., few pods remained green even after secession of rains. 
Table.1 Evaluation of Sunhemp genotypes for yield and yield components at Agricultural Research Station, Nathnaipally during Kharif, 2018

\begin{tabular}{|c|c|c|c|c|c|c|c|c|c|c|}
\hline Genotype & $\begin{array}{c}\text { Days to } \\
\mathbf{5 0 \%} \\
\text { Flowering }\end{array}$ & $\begin{array}{l}\text { Days to } \\
\text { maturity }\end{array}$ & $\begin{array}{c}\text { Plant } \\
\text { Height }(\mathrm{cm})\end{array}$ & $\begin{array}{c}\text { No. of } \\
\text { branches }\end{array}$ & $\begin{array}{c}\text { No of } \\
\text { Shattered } \\
\text { pods }\end{array}$ & $\begin{array}{c}\text { Number } \\
\text { of dry } \\
\text { pods }\end{array}$ & $\begin{array}{c}\text { Number } \\
\text { of Green } \\
\text { pods }\end{array}$ & $\begin{array}{c}\text { No.of } \\
\text { Seed/Pod }\end{array}$ & TW (g) & $\begin{array}{c}\text { Seed yield/ } \\
\text { Plant (g) }\end{array}$ \\
\hline $\begin{array}{l}\text { NTPSH- } \\
01\end{array}$ & 69 & 139 & $114^{*}$ & $5.8^{*}$ & 0 & $88 *$ & 0 & 11.1 & 2.4 & $20.97 *$ \\
\hline $\begin{array}{l}\text { NTPSH- } \\
02\end{array}$ & 71 & 139 & $115.6^{*}$ & $6.2 *$ & 0 & $116.6^{*}$ & 0 & 11.3 & 2.9 & $21.75^{*}$ \\
\hline $\begin{array}{l}\text { NTPSH- } \\
03\end{array}$ & 72 & 140 & $123.6^{*}$ & $6.2 *$ & 0 & $116.2 *$ & 0 & 12 & 2.6 & $26.12 *$ \\
\hline $\begin{array}{l}\text { NTPSH- } \\
04\end{array}$ & 70 & 138 & 91 & $5.8 *$ & 0 & $142.2 *$ & 0 & 8.2 & 3.6 & $27.77 *$ \\
\hline $\begin{array}{l}\text { NTPSH- } \\
05\end{array}$ & $76^{*}$ & 142 & 83.6 & 3.8 & 0 & $82.4 *$ & 0 & 6.8 & $4.5^{*}$ & 14.04 \\
\hline $\begin{array}{l}\text { NTPSH- } \\
06\end{array}$ & 68 & 136 & $111.2 *$ & $7.8^{*}$ & 0 & 65 & 0 & 10.4 & 2.7 & 13.92 \\
\hline $\begin{array}{l}\text { NTPSH- } \\
07\end{array}$ & 72 & 140 & 88.6 & 4 & 0 & 47.4 & 0 & 9.6 & 2.8 & 13.3 \\
\hline $\begin{array}{l}\text { NTPSH- } \\
08\end{array}$ & $76^{*}$ & 142 & $100.4 *$ & $5.8^{*}$ & 0 & $71^{*}$ & 0 & $12.8^{*}$ & 2.6 & 17.3 \\
\hline $\begin{array}{l}\text { NTPSH- } \\
09\end{array}$ & $75^{*}$ & 148 & 89 & $6.4^{*}$ & 0 & $112.4^{*}$ & 0 & $12.3 *$ & 2 & $21.41 *$ \\
\hline Check (L) & 72 & 146 & 89.6 & 4 & 0 & 48.2 & 0 & 10.2 & 2.6 & 13.48 \\
\hline Mean & 72.10 & 141.00 & 100.66 & 5.58 & 0.00 & 88.94 & 0.00 & 10.47 & 2.87 & 19.01 \\
\hline Range & $68-76$ & $136-148$ & $43.6-83.6$ & $3.8-7.8$ & 0 & $47.4-116.6$ & 0 & $6.8-12.8$ & $2-4.5$ & $13.3-27.77$ \\
\hline $\mathbf{C V}$ & 8.9 & 7.6 & 15.6 & 11.2 & $* *$ & 14.8 & $* *$ & 12.6 & 11.3 & 14.6 \\
\hline $\operatorname{CD}(5 \%)$ & 1.86 & 3.86 & 5.48 & 1.48 & $* *$ & 21.36 & $* *$ & 1.58 & 1.2 & 6.8 \\
\hline
\end{tabular}


Table.2 Evaluation of Dhaincha genotypes for yield and yield components at Agricultural Research Station, Nathnaipally during Kharif, 2018

\begin{tabular}{|c|c|c|c|c|c|c|c|c|c|c|}
\hline Genotype & $\begin{array}{c}\text { Days to } \\
\mathbf{5 0 \%} \\
\text { Flowering }\end{array}$ & $\begin{array}{l}\text { Days to } \\
\text { Maturity }\end{array}$ & $\begin{array}{c}\text { Plant } \\
\text { height } \\
\text { (cm) }\end{array}$ & $\begin{array}{c}\text { No. of } \\
\text { Branches }\end{array}$ & $\begin{array}{l}\text { No of pods } \\
\text { Shattered }\end{array}$ & $\begin{array}{l}\text { No of dry } \\
\text { pods }\end{array}$ & $\begin{array}{l}\text { No of } \\
\text { green } \\
\text { pods }\end{array}$ & $\begin{array}{c}\text { No. of } \\
\text { seeds/pod }\end{array}$ & TW(g) & $\begin{array}{l}\text { Seed yield/ } \\
\text { Plant (g) }\end{array}$ \\
\hline NTPD- 01 & 49 & 128 & 266.6 & 14.8 & 0 & $73.6^{*}$ & 0 & 21.4 & 2.104 & $33.71 *$ \\
\hline NTPD- 02 & 46 & 126 & 247.6 & $23 *$ & 10 & $70.8 *$ & $26.3 *$ & 26 & 2.14 & $25.87^{*}$ \\
\hline NTPD- 03 & 48 & 127 & $279.4^{*}$ & 21.8 & 12 & $71.4^{*}$ & 14.8 & 26.3 & 2.404 & 19.68 \\
\hline NTPD- 04 & 50 & 128 & 252.2 & 20.8 & $15.2 *$ & 46.8 & $23.8^{*}$ & 24.6 & 2.404 & 14.46 \\
\hline NTPD- 05 & 50 & $136 *$ & 245.8 & 16.8 & $13.4 *$ & 30.6 & $32.8 *$ & 29.2 & 2.161 & 19.84 \\
\hline NTPD- 06 & 47 & 124 & 260.8 & $22.8^{*}$ & 0 & 101 & 0 & 26.3 & 2.23 & $32.34^{*}$ \\
\hline NTPD- 07 & 46 & 126 & 226 & 17 & 0 & $75.2^{*}$ & 0 & 23.2 & 2.142 & $29.03 *$ \\
\hline NTPD- 08 & 47 & 127 & $282.2 *$ & $24.6^{*}$ & 0 & $97.2^{*}$ & 0 & $31.2 *$ & 2.391 & $34.67 *$ \\
\hline NTPD- 09 & 50 & 124 & $287.2 *$ & $23.6^{*}$ & 9.6 & 44.6 & 19.6 & 24.7 & 2.418 & 15.06 \\
\hline NTPD- 10 & $51 *$ & 123 & 260 & 19.8 & 13.2 & $55.8^{*}$ & $47.2 *$ & 26 & 2.339 & 20.05 \\
\hline Check & 49 & 128 & 267.3 & 18.2 & 10.2 & 46.4 & 16.2 & 26.3 & 2.342 & 14.68 \\
\hline Mean & 48.45 & 127.00 & 261.37 & 20.29 & 7.60 & 64.85 & 16.43 & 25.93 & 2.28 & 23.58 \\
\hline Range & $46-51$ & $123-136$ & $226-287.2$ & $14.8-24.6$ & $0-15.2$ & 30.6-101 & $0-47.2$ & $21.4-31.2$ & $\begin{array}{c}2.091- \\
2.418\end{array}$ & $\begin{array}{l}14.46- \\
34.67\end{array}$ \\
\hline $\mathbf{C V}$ & 3.2 & 2.8 & 6.3 & 10.6 & 12.6 & 16.3 & 12.8 & 9.8 & 2.36 & 11.2 \\
\hline $\operatorname{CD}(5 \%)$ & 1.96 & 2.36 & 8.6 & 3.9 & 3.2 & 8.61 & 6.42 & 4.36 & 0.962 & 5.69 \\
\hline
\end{tabular}


Even though harvesting was delayed the pods remained green. However, in four genotypes viz., NTPD 01, NTPD 06, NTPD 07 and NTPD 08 synchronous maturity was noticed with nil (0) green pods at maturity. Highest number of green pods observed in NTPD 10 (47.2) followed by NTPD 05 (32.8). Compared to the check (16.2) significantly more number of pods observed in NTPD 02, NTPD 04, NTPD 05 and NTPD 10.

\section{Number of seeds per pod}

Average number of seeds per pod in Sunhemp recorded was 10.47 with a range of 6.8 (NTPSH 05) to 12.8 (NTPSH 08). Similarly highest number of seeds observed in Dhaincha was 31.2 in NTPD 08 followed by 29.2 in NTPD 05. While it was least (21.4) in NTPD 01 with mean value of 25.93 among 11 genotypes.

Definitely more number of seeds per pod will have positive correlation with seed yield for selection. Significantly highest number of seeds per pod observed in Sunhemp genotypes NTPSH 08 and NTPSH 09 compared to the check (10.2). While it was one Dhaincha genotype (NTPD 08) compared to check (26.3).

\section{Test weight (g)}

The average test weight was $2.87 \mathrm{~g}$ with a range varying from 2.0 to $4.5 \mathrm{~g}$ in Sunhemp. NTPSH 09 had lighter seeds $(2.0 \mathrm{~g})$ while NTPSH 05 recorded heavier seed $(4.5 \mathrm{~g})$. This trait can be improved through heterosis breeding. Similarly, 2.104 (NTPD 01) to $2.418 \mathrm{~g}$ (NTPD 09) test weight was recorded in Dhaincha with mean value observed was 2.28 g. Significantly superior test weight observed in NTPSH 05 over check (2.6) in Sunhemp. Where as in Dhaincha non of the genotype significantly superior over check $(2.342 \mathrm{~g})$.

\section{Seed yield per plant (g)}

Seed yield per plant exhibited a wide amount of variation varying from 13.30 to $27.77 \mathrm{~g}$ per plant in Sunhemp. The overall mean was 18.94 g. Highest seed yield recorded in NTPSH 04 (27.77 g) followed by NTPSH 03 $(26.12 \mathrm{~g})$. Whereas in Dhaincha, the lowest seed yield recorded in NTPD 04 (14.46 g) and highest in NTPD 08 (34.67 g).

However the high biomass production in terms of root and shoot is criteria in green manures. Selection will be effective for entry with high biomass and high seed yield. Significantly superior seed yield/plant observed in NTPSH 01, NTPSH 02, NTPSH 03, NTPSH 04 and NTPSH 09 over check (13.8 g). Where as in Dhaincha six genotypes namely, NTPD 01, NTPD 02, NTPD 06, NTPD 07 and NTPD 08 recorded significantly superior yield over check (14.68 g)(Triveni, 2011).

\section{References}

Chandrasekhar P., 2013. Seed production of Sunhemp (Crotalaria juncea L.) as influenced by sowing time. M.Sc. Thesis, Agricultural College, Bapatla.

M. K. Tripathi, Babita Chaudhary and H. R. Bhandari, 2013. Growth and yield of sunnhemp (Crotalaria juncea L.) as influenced by spacing and topping practices. African Journal of Agricultural Research, 8(28)3744-3749.

Triveni U., 2011. Seed production of Dhaincha (Sesbania aculeata (Wills. Poir.) as influenced by sowing time and planting density. M.Sc. Thesis, Agricultural College, Bapatla.

Venkanna B,2014. Influence of row spacing and phosphorus levels on seed production of Dhaincha (Sesbania aculeata). Agrotechnology, 2(4): 327- 329. 


\section{How to cite this article:}

Shobha Rani, T., T. Sukruth Kumar, U. Nagabhushanam and Jaganmohan Rao, P. 2020. Rainfed Evaluation of Genotypes for Seed Yield and Yield Components in Sunhemp (Crotalaria juncea L.) and Dhaincha (Sesbania aculeata L.). Int.J.Curr.Microbiol.App.Sci. 9(04): 1022-1029. doi: https://doi.org/10.20546/ijcmas.2020.904.121 